MICHAŁ ROMANOWSKI

PIOTR HAIDUK

https://doi.org/10.33995/wu2021.4.2

\title{
Ocena przepisów poświęconych funkcjonowaniu Rad Nadzorczych w związku z projektem ustawy - o zmianie ustawy - Kodeks spółek handlowych oraz niektórych innych ustaw
}

Celem artykułu jest ocena przepisów poświęconych funkcjonowaniu rad nadzorczych, w tym w kontekście spółek akcyjnych prowadzq̨cych działalność ubezpieczeniowq, w zwiqzzu z projektem ustawy - o zmianie ustawy - Kodeks spółek handlowych oraz niektórych innych ustaw (Druk nr 1515), dalej: projekt lub nowelizacja.

Projekt przedstawiany jest jako mechanizm do aktywizacji rad nadzorczych i opiera się na założeniu, że obecne przepisy maja promować bierność członków rady nadzorczej. Rada nadzorcza ma być bierna, bo miałaby nie mieć narzędzi do efektywnego nadzoru. Całkowicie pominięto przy tym rozbudowane regulacje dotyczqce nadzoru korporacyjnego $w$ instytucjach finansowych ( $w$ tym w szczególności w zakładach ubezpieczeń].

Projekt został oparty na błędnych założeniach i w niedopracowany (a miejscami wręcz infantylny) sposób proponuje rozwiqzania, które mogq sparaliżować funkcjonowanie nadzoru w spółkach akcyjnych. Wbrew deklarowanym intencjom projektodawców, w istocie rzeczy może on doprowadzić do osłabienia ochrony interesów akcjonariuszy.

Słowa kluczowe: rada nadzorcza, komitet audytu, spółki akcyjne, obowiązki informacyjne.

\section{Wstęp}

Omawiane przepisy przedstawiane sa przez projektodawców jako mechanizm do aktywizacji rad nadzorczych. Mają temu służyć w szczególności następujące instytucje:

1) obowiazki informacyjne zarządu wobec rady nadzorczej, w tym: 
a) obowiązek „pchania informacji” do rady nadzorczej (projektowany art. $380^{1}$ k.s.h. ${ }^{1}$ );

b) rozszerzenie obowiązków udzielenia odpowiedzi na pytania rady nadzorczej na osoby inne niż członkowie zarządu (projektowany art. $382 \S 4,4^{1}$ oraz $4^{2}$ k.s.h. ${ }^{2}$ ),

2) możliwość reprezentacji spółki przez radę nadzorczą przy zawieraniu umów z doradcą rady nadzorczej (projektowany art. $382^{1} \S 3$ k.s.h. ${ }^{3}$ );

3) zabezpieczenie wykonania obowiązków informacyjnych przez członków zarządu, ale także pracowników oraz współpracowników przepisami karnymi (projektowany art. $587^{1}$ oraz art. $587^{2}$ k.s.h. ${ }^{4}$ ).

1. Art. $380^{1}$ k.s.h.:

„§ 1. Zarząd jest obowiązany, bez dodatkowego wezwania, do udzielenia radzie nadzorczej w szczególności informacji o:

1) uchwałach zarządu i ich przedmiocie;

2) sytuacji spółki, w tym w zakresie jej stanu majątkowego, a także istotnych okolicznościach z zakresu prowadzenia spraw spółki, w szczególności w obszarze operacyjnym, inwestycyjnym i kadrowym;

3) postępach w realizacji wyznaczonych kierunków rozwoju działalności spółki, przy czym zarząd powinien wskazać na odstępstwa od wcześniej wyznaczonych kierunków, podając zarazem uzasadnienie odstępstw;

4) transakcjach oraz innych zdarzeniach lub okolicznościach, które istotnie wpływają lub mogą wpływać na sytuację majątkową spółki, w tym na jej rentowność lub płynność;

5] zmianach uprzednio udzielonych radzie nadzorczej informacji, jeżeli zmiany te istotnie wpływają lub mogą wpływać na sytuację spółki.

§ 2. Obowiązek, o którym mowa w $§ 1$ pkt 2-5, obejmuje posiadane przez zarząd informacje dotyczące spółek zależnych oraz spółek powiązanych.

$\S 3$. Informacje, o których mowa w $\S 1$ i 2 , powinny być przekazywane:

1) w przypadku, o którym mowa w $\S 1$ pkt 1-3 - na każdym posiedzeniu rady nadzorczej, chyba że rada nadzorcza postanowi inaczej;

2) w przypadku, o którym mowa w $§ 1$ pkt 4 i 5 - niezwłocznie po wystapieniu określonych zdarzeń lub okoliczności.

$\S 4$. Informacje, o których mowa w $\S 1$ i 2, powinny być przedstawione na piśmie, z wyjątkiem sytuacji, gdy zachowanie tej formy nie jest możliwe ze względu na konieczność natychmiastowego przekazania informacji radzie nadzorczej. Rada nadzorcza może postanowić o dopuszczalności przekazywania tych informacji również w innej formie.

$\S 5$. Statut może wyłączać albo ograniczać obowiązki informacyjne określone w $§ 1$ lub 2".

2. Art. $382 \S 4,4^{1}$ oraz $4^{2}$ k.s.h.:

"§4. W celu wykonania swoich obowiązków rada nadzorcza może badać wszystkie dokumenty spółki, dokonywać rewizji stanu majątku spółki oraz żądać od zarządu, prokurentów, likwidatorów, osób zatrudnionych w spółce na podstawie umowy o pracę lub wykonujących na rzecz spółki w sposób regularny określone czynności na podstawie umowy o dzieło, umowy zlecenia albo innej umowy o podobnym charakterze sporzadzenia lub przekazania wszelkich informacji, dokumentów, sprawozdań lub wyjaśnień dotyczących spółki, w szczególności jej działalności lub stanu majątkowego. Przedmiotem żądania mogą być również posiadane przez jego adresata informacje, sprawozdania lub wyjaśnienia dotyczące spółek zależnych oraz spółek powiązanych.

$\S 4^{1}$. Informacje, dokumenty, sprawozdania lub wyjaśnienia, o których mowa w $\S 4$, są przekazywane radzie nadzorczej niezwłocznie, nie później niż w terminie dwóch tygodni od dnia zgłoszenia żądania do organu lub osoby obowiązanej, chyba że w żądaniu określono dłuższy termin.

$\S 4^{2}$. Zarząd nie może ograniczać członkom rady nadzorczej dostępu do żądanych przez nich informacji, dokumentów, sprawozdań lub wyjaśnień".

3. Art. $382^{1} \S 3:$ „W umowie między spółką a doradcą rady nadzorczej spółkę reprezentuje rada nadzorcza”.

4. Projektowany art. $587^{1}$ k.s.h.: „Kto, wbrew obowiązkom wynikającym z art. $219 \S 4 \mathrm{i} 4^{1}$, art. $300^{71} \S 1-2$, art. $300^{76}$ $\S 5$ albo art. $382 \S 4 i 4^{1}$, nie przekazuje w terminie lub przekazuje informacje, dokumenty, sprawozdania lub wyjaśnienia niezgodne ze stanem faktycznym, lub zataja dane wpływające w istotny sposób na treść tych informacji, dokumentów, sprawozdań lub wyjaśnień - podlega grzywnie nie niższej niż 20000 złotych i nie wyższej niż 50000 złotych albo karze ograniczenia wolności. Jeżeli sprawca działa nieumyślnie - podlega grzywnie nie niższej niż 6000 złotych i nie wyższej niż 20000 złotych” oraz art. $587^{2}$ k.s.h.: ,Kto, wbrew obowiązkom wynikającym z art. $219^{2} \S 4$, art. $300^{71 a} \S 4$ albo art. $382^{1} \S 4$, nie przekazuje w terminie lub przekazuje informacje, dokumenty, wyjaśnienia lub 
Jedynie na marginesie można zauważyć, że projektodawcy pozostawili jako domyślny model zaktywizowanej rady nadzorczej, która spotyka się 4 razy w roku ${ }^{5}$ (projektowany art. 389 § 7 k.s.h.).

Czytając projektowane przepisy, nie sposób oprzeć się wrażeniu, że pisały je osoby bez doświadczenia legislacyjnego. Stąd też szereg regulacji został ujęty w sposób, który raczej można znaleźć w regulaminie rady nadzorczej niż w ustawie rangi kodeksowej. Autorzy zapominają bowiem o tym, że cele dokumentów korporacyjnych oraz regulacji ustawowej (szczególnie uwzględniając zasadę ścisłości statutu] są całkowicie odmienne. Inny jest też sposób wykładni postanowień takich dokumentów i inne skutki ich wadliwej redakcji. Przykłady można mnożyć. Ograniczone ramy artykułu pozwalaja przedstawić tylko najbardziej jaskrawe z nich.

\section{Rada nadzorcza a zawarcie umowy z doradcą rady nadzorczej}

Wprowadzając możliwość reprezentowania spółki przez radę nadzorczą przy zawieraniu umowy z doradca (sama możliwość korzystania z doradców jest powszechna w praktyce), projektodawcy wskazali, że: „[d] oradcą rady nadzorczej może być wyłącznie podmiot posiadający wiedzę fachową i kwalifikacje niezbędne do zbadania sprawy określonej przez radę nadzorcza, który zapewnia sporzadzenie rzetelnego i obiektywnego raportu z badania" (projektowany art. $382^{1} \S 2$ zdanie pierwsze k.s.h.).

Trudno tę regulację nazwać inaczej jak infantylna. Projektodawcy nie dostrzegli prawdopodobnie, że kryje się za nią istotne ryzyko praktyczne. Wpisanie bowiem do przepisu prawa kwestii oczywistych (postulatu korzystania z profesjonalnych doradców) rodzi bowiem określone konsekwencje. ${ }^{6}$ Zgodnie z art. 58 § 1 k.c. czynność prawna sprzeczna z ustawaj jest bezwzględnie nieważna. Czy oznacza to, że jeżeli doradca rady nadzorczej nie będzie zapewniać obiektywności (względem czego?), to zawarta z nim umowa będzie nieważna? Kto będzie to oceniał? Zarząd, w momencie w którym będzie musiał zapłacić za pracę doradcy? Warto przy tym pamiętać, że o ile nowością jest obowiązek reprezentacji spółki przez radę nadzorczą przy zawieraniu umowy z doradcą rady nadzorczej? , o tyle w praktyce o zapłacie wynagrodzenia za pracę doradcy decydować będzie i tak zarząd. Rada nadzorcza nie ma bowiem dostępu do rachunków bankowych spółki.

Zgodnie z $\S 6$ zdanie pierwsze projektowanego przepisu doradca rady nadzorczej ma sporzadzić pisemny raport z badania. Czy forma dokumentowa będzie wystarczająca, czy raport trzeba będzie opatrywać kwalifikowanym podpisem elektronicznym? Jakie będą skutki niedochowania tego wymogu? Powyższe pytania prowadzą zaś do pytania zasadniczego - czemu w ogóle ma służyć zastrzeżenie tego wymogu na poziomie ustawy?

oświadczenia niezgodne ze stanem faktycznym, lub zataja dane wpływające w istotny sposób na treść tych informacji, dokumentów, wyjaśnień lub oświadczeń - podlega grzywnie nie niższej niż 20000 złotych i nie wyższej niż 50000 złotych albo karze ograniczenia wolności. Jeżeli sprawca działa nieumyślnie - podlega grzywnie nie niższej niż 6000 złotych i nie wyższej niż 20000 złotych".

5. Już obecnie rozwiązanie to uważane jest za dysfunkcyjne i uniemożliwiające efektywne sprawowanie nadzoru - por. zamiast wielu: A. Opalski, Komentarz do art. 389 k.s.h., nb. ?, [w:] Kodeks spółek handlowych. Tom III A. Spółka akcyjna. Komentarz do art. 301-392, [red.] A. Opalski, Warszawa 2016, Legalis 2021.

6. Por. Opinia Rady Legislacyjnej przy Prezesie Rady Ministrów z 16 października 2020 r. o projekcie ustawy o zmianie ustawy - Kodeks spółek handlowych oraz niektórych innych ustaw ( Nr RL-033-28/20).

?. Projektowany art. $382^{1} \S 3$ k.s.h. 
W konsekwencji powstaje pytanie: czy nowelizacja faktycznie upraszcza korzystanie przez radę nadzorczą z zewnętrznych doradców, czy raczej utrudnia tę kwestię?

\section{Czy problem faktycznie występuje, a jeżeli tak, to co jest jego przyczyną?}

Projekt opiera się na założeniu, że obecne przepisy Kodeksu spółek handlowych promują bierność członków rady nadzorczej. Rada nadzorcza jest bierna, bo nie ma narzędzi do efektywnego nadzoru. Trzeba zatem zmienić przepisy i dostarczyć członkom rady nadzorczej narzędzia, aby bierni nie byli.

Zanim przejdzie się do zmieniania przepisów prawa (i to rangi kodeksowej), należy sobie odpowiedzieć na pytanie, czy problem, który chce się rozwiązać, w ogóle występuje w rzeczywistości i jak sobie radzi z nim obecny system prawny. Czy problemem są wadliwe przepisy - względnie ich brak - czy też może stosowanie tych przepisów? Jeżeli potrzeba wprowadzenia nowych regulacji faktycznie istnieje, to trzeba także zadać pytanie o to, jakie będą ich prognozowane skutki - podstawowe oraz uboczne. Czy problem dotyczy wszystkich spółek akcyjnych?

W uzasadnieniu projektu próżno szukać rzetelnej odpowiedzi na tak postawione pytania. Wszakże pytania te wprost wynikają z rozporządzenia Prezesa Rady Ministrów z dnia 20 czerwca 2002 roku w sprawie „Zasad techniki prawodawczej”. Mimo upływu przeszło 20 lat rozporządzenie to nie straciło na aktualności.

Tymczasem autorzy całkowicie pominęli fakt, że problem regulacji modelowego nadzoru nad spółką akcyjną dotyczy w zasadzie wyłącznie spółek o charakterze otwartym, o rozproszonym akcjonariacie. W polskich realiach gospodarczych jest to 425 spółek publicznych notowanych na rynku głównym Giełdy Papierów Wartościowych w Warszawie (według stanu na 19 października 2021 roku). Do tej liczby należy dodać 372 spółki notowane na NewConnect (według stanu 15 października 2021 roku). To łącznie ok. 800 podmiotów, czyli mniej niż 10\% wszystkich spółek akcyjnych w Polsce (na koniec 2020 roku było ich $9880^{\circ}$ ).

Projektodawcy pomijaja przy tym fakt, że do spółek notowanych stosuje się rozbudowany reżim informacyjny z rozporządzenia MAR ${ }^{10}$ pod nadzorem Komisji Nadzoru Finansowego, a szereg z nich (w tym wszystkie zakłady ubezpieczeń) spełnia definicję jednostek zainteresowania publicznego z ustawy o biegłych rewidentach, firmach audytorskich oraz nadzorze publicznym ${ }^{11}$. Przepisy te wymagaja rozbudowanego nadzoru nad działalnością spółki, a także powołania komitetu audytu rady nadzorczej ${ }^{12}$. Zasady funkcjonowania tych spółek obejmowane są dobrymi praktykami z zakresu ładu korporacyjnego. Spółki publiczne, a szczególnie jednostki zainteresowania publicznego, projektowanych zmian zatem po prostu nie potrzebują.

8. Tekst jedn. Dz. U. z dnia 7.03.2016 r., poz. 283.

9. GUS, Zmiany strukturalne grup podmiotów gospodarki narodowej w rejestrze REGON, 2020 r., Warszawa 2021, s. 138.

10. Rozporządzenia Parlamentu Europejskiego i Rady (UE) nr 596/2014 z dnia 16.04.2014 r. w sprawie nadużyć na rynku (rozporządzenie w sprawie nadużyć na rynku) oraz uchylające dyrektywę 2003/6/WE Parlamentu Europejskiego i Rady i dyrektywy Komisji 2003/124/WE, 2003/125/WE i 2004/72/WE.

11. Ustawa z dnia 11.05.2017 r. o biegłych rewidentach, firmach audytorskich oraz nadzorze publicznym (tekst jedn. Dz. U. 2020, poz. 1415, z późn. zm., dalej: u.b.r.).

12. Zamiast wielu zob. A. Opalski, op. cit. 
Tym bardziej nie potrzebują ich pozostałe spółki akcyjne, które mają charakter zamknięty. Spółki te mają skoncentrowany akcjonariat i w swojej naturze zbliżają się do spółek z ograniczoną odpowiedzialnością. 0 zasadach nadzoru nad takimi spółkami decydują akcjonariusze. Nie potrzebuja oni paternalistycznego i infantylnego podejścia ze strony ustawodawcy i narzucania im mechanizmów nadzorczych. Dodać można, że mechanizmów, które są fatalnie napisane i niosą za sobą bardzo groźne konsekwencje. Projektodawcom udała się bowiem rzecz niezwykle trudna. Stworzyli przepisy, które jednocześnie narażają na potężne ryzyko prawne członków zarządu, pracowników i współpracowników spółek, utrudniają działanie rad nadzorczych, a jednocześnie paradoksalnie uderzają w interesy akcjonariuszy. Akcjonariusze takich spółek poniosą zatem wyłącznie dodatkowe koszty związane z zarządzeniem nowymi przepisami, nie odnosząc żadnych korzyści.

Projekt powstał w komisji przy Ministerstwie Aktywów Państwowych. Jeżeli problem, który zdiagnozowali projektodawcy, dotyczy nadzoru nad spółkami z udziałem Skarbu Państwa to istnieje dedykowana im ustawa o zasadach zarządzania mieniem państwowym ${ }^{13}$. Można z niej skorzystać (chociaż problemu nadzoru to nie rozwiąże, bo przyczyny jego niedomagania leżą gdzie indziej), zamiast zaśmiecać Kodeks spółek handlowych ze szkodą dla biznesu prywatnego.

Jeżeli zaś wreszcie projektowane regulacje wynikają z incydentalnych problemów, z którymi zderzyli się autorzy przepisów, to należało sobie zadać pytanie, czy na regulację zasady należy patrzeć przez pryzmat wyjątku oraz czy projekt przyniesie więcej pożytku niż szkody.

W uzasadnieniu projektu próżno szukać także dowodu na prawdziwość tezy o tym, że to obecne regulacje prawne promują bierność członków rady nadzorczej. Dostrzec można za to, że autorom projektu umknęły w zasadzie wszystkie przepisy Kodeksu spółek handlowych dające radzie nadzorczej szerokie uprawnienia nadzorcze. Jeżeli dodać do tego bardzo rozbudowane przepisy dotyczące ładu korporacyjnego instytucji finansowych (czy też: jednostek zainteresowania publicznego) w tym w szczególności zakładów ubezpieczeń - można dojść do wniosku, że nowelizacja opiera się na całkowicie błędnym rozpoznaniu przez projektodawców rzeczywistego stanu prawnego.

\section{Obecna regulacja Kodeksu spółek handlowych}

Rada nadzorcza ma prawo sprawowania stałego nadzoru nad działalnością spółki we wszystkich dziedzinach jej działalności (art. 382 § 1 k.s.h.). Rada nadzorcza ma prawo do wgladu we wszyst$\mathrm{ko}^{14}$. Jest bowiem reprezentantem akcjonariuszy - właścicieli spółki, którzy powierzyli zarządowi zarządzanie ich majątkiem. Wystarczy „myśleć zasadami” i znać istniejące reguły lub umieć je wyprowadzać z zasad.

Członkowie zarządu podlegają ograniczeniom ustanowionym m.in. w statucie, regulaminie zarządu oraz w uchwałach rady nadzorczej i walnego zgromadzenia (art. $375 \S 1$ k.s.h.). Walne zgromadzenie może uchwalić regulamin rady nadzorczej, określający jej organizację i sposób wykonywania czynności. Statut może wprost upoważnić radę do uchwalenia jej regulaminu (art. 391 § 3 k.s.h.). A w aktach tych można „na miarę” danej spółki „uszyć” szczegółowe zasady nadzoru wiążące zarzạd.

13. Ustawa z dnia 16.12.2016 r. o zasadach zarządzania mieniem państwowym (tekst jedn. Dz. U. 2020, poz. 735).

14. Zob. np. A. Opalski, op. cit. 
Do obowiązków rady nadzorczej należy ocena sprawozdań zarządu z działalności spółki i sprawozdań finansowych w zakresie ich zgodności z księgami i dokumentami, jak i ze stanem faktycznym, a także składanie walnemu zgromadzeniu corocznego pisemnego sprawozdania z wyników tej oceny (art. 382 § 3 k.s.h.).

Rada nadzorcza może badać wszystkie dokumenty spółki, żądać od zarządu i pracowników sprawozdań i wyjaśnień ${ }^{15}$ oraz dokonywać rewizji stanu majątku spółki (art. 382 § 3 k.s.h.). Nie jest prawda, że rada jest skazana na komunikację wyłącznie z zarządem, chociaż powinien to być jej podstawowy partner ${ }^{16}$. Wszak modelowo to rada nadzorcza dobiera sobie partnera, powołując i odwołując członków zarządu (art. 368 § 4 k.s.h.) ${ }^{17}$. Jeżeli rada nadzorcza jest takich instrumentów pozbawiona, to jest to decyzja akcjonariuszy. Modelowo to także rada nadzorcza dobiera adekwatne bodźce wpływające na zachowania zarządu, ustalając jego wynagrodzenie (art. 378 $\S 1$ k.s.h.). Członek zarządu może być odwołany w każdym czasie (art. 370 § 1 k.s.h.). Uchwała walnego zgromadzenia lub statut spółki może określać wymagania, jakie powinni spełniać kandydaci na stanowisko członka zarządu (art. 368 § 5 k.s.h.). Członek zarządu może być powoływany przez radę nadzorcza po przeprowadzeniu postępowania kwalifikacyjnego ( $\operatorname{art} .368^{1} \S 1$ k.s.h.). Do kompetencji rady nadzorczej należy zawieszanie, z ważnych powodów, członków zarządu oraz delegowanie członków rady do czasowego wykonywania czynności m.in. odwołanych członków zarządu (art. 383 § 1 k.s.h.). Nie ma lepszego mechanizmu oddziaływania na zarząd niż prawo do jego powołania, odwołania, zawieszania i kształtowania wynagrodzenia, w tym w części zmiennej. Trzeba tylko potrafić budować KPI (kluczowe wskaźniki efektywności).

Statut może rozszerzyć uprawnienia rady nadzorczej, a w szczególności przewidywać, że zarząd jest obowiązany uzyskać jej zgodę przed dokonaniem określonych czynności (art. 384 § 1 k.s.h.] - i w praktyce takie zgody korporacyjne powszechnie wprowadza. Rada nadzorcza może zatem współdecydować o sprawach kluczowych dla spółki ${ }^{18}$. Jak wskazuje wprost Adam Opalski:

15. Tak trafnie W. Popiołek: „Osoby, do których rada zwraca się o udzielenie wyjaśnień (sprawozdań), są obowiązane ich udzielić. Dotyczy to także, moim zdaniem, nie tylko pracowników w rozumieniu prawa pracy, ale także innych osób świadczących na rzecz spółki usługi na podstawie innego stosunku prawnego niż stosunek pracy [w związku z częsta praktyką outsourcingu niektórych rodzajów działalności]; odmiennie Rodzynkiewicz, Komentarz KSH, 2014, s. 408. Zarząd nie może ograniczać dostępu członków rady nadzorczej do żądanych przez nich informacji" - W. Popiołek, Komentarz do art. 382, nb. 6, [w:] Kodeks spółek handlowych. Komentarz, [red.] J. Strzępka, Warszawa 2015, Legalis 2021.

16. Jak znów trafnie wskazuje W. Popiołek: „Oznacza to obowiązek stałego nadzorowania nie tylko pracy zarzadu, ale wszystkich pracowników, funkcjonowania spółki w stosunkach wewnętrznych (organizacja przedsiębiorstwa) i zewnętrznych, spraw korporacyjnych (np. prawidłowość zwoływania walnych zgromadzeń), itd." - W. Popiołek, Komentarz do art. 382, nb. 3, [w: Kodeks spółek handlowych. Komentarz, [red.] J. Strzępka, Warszawa 2015, Legalis 2021. Jak trafnie wskazuje A. Opalski w ślad za S. Sołtysińskim, rada nadzorcza może obecnie pozyskiwać informacje od osób trzecich za pośrednictwem zarządu lub pracowników spółki, co w praktyce obejmuje pełny dostęp do informacji o spółce - A. Opalski, Komentarz do art. 382, nb. 19, [w: ] Kodeks spółek handlowych. Tom III A. Spółka akcyjna. Komentarz do art. 301-392, [red] A. Opalski, Warszawa 2016, Legalis 2021.

17. A. Opalski trafnie wskazuje, że uprawnienie to de facto umożliwia wpływanie na prowadzenie spraw spółki przez radę nadzorczą - A. Opalski, Komentarz do art. 384, nb. 1, [w:] Kodeks spółek handlowych. Tom III A. Spółka akcyjna. Komentarz do art. 301-392, [red] A. Opalski, Warszawa 2016, Legalis 2021.

18. Zob. np. J. Szwaja, I. Mika, Komentarz do art. 384 k.s.h., nb. 12 [w:] Kodeks spółek handlowych. Komentarz. Tom 3, [red.] S. Sołtysiński, A. Szajkowski, A. Szumański, Warszawa 2013, Legalis 2021. 
„Rada ma w ten sposób szansę zyskać rolę gremium strategicznego, współdecydującego wraz z zarządem o najważniejszych kierunkach rozwoju spółki”19.

Rada nadzorcza może delegować swoich członków do samodzielnego pełnienia określonych czynności nadzorczych (art. 390 § 1 k.s.h.). Przełamuje to zasadę kolegialności RN20 i umożliwia codzienny kontakt jej reprezentanta nie tylko z zarządem, ale również z pracownikami, doradcami i kontrahentami spółki. Jeżeli rada nadzorcza została wybrana w drodze głosowania oddzielnymi grupami, każda grupa ma prawo delegować jednego spośród wybranych przez siebie członków do stałego indywidualnego wykonywania czynności nadzorczych. Członkowie ci maja prawo uczestniczenia w posiedzeniach zarządu z głosem doradczym. Zarząd obowiązany jest zawiadomić ich uprzednio o każdym swoim posiedzeniu (art. 390 § 2 k.s.h.). Prawidłowa wykładnia powołanych przepisów pozwala na zastosowanie tego mechanizmu kontroli korporacyjnej także do członków rady niewybranych w drodze głosowania grupami. Już zatem obecne przepisy Kodeksu spółek handlowych kreują równolegle działający obok rady nadzorczej jednoosobowy „organ” sprawujący bieżącą kontrolę nad zarządem i mający dostęp do informacji o spółce jak zarząd.

\section{Obowiązki informacyjne zarządu wobec rady nadzorczej a wymiana informacji wynikająca z obecnie obowiązujących przepisów}

Autorzy projektowanej nowelizacji zapomnieli także, że szereg przepisów branżowych - dostosowanych do specyfiki działania w danym sektorze - zawiera już wyczerpujące regulacje z zakresu ładu korporacyjnego, w tym z zakresu sprawowania nadzoru nad spółkami. Jest to zresztą zrozumiałe i wynika z aksjologii systemu prawnego. Jeżeli sposób prowadzenia spraw danej spółki (np. instytucji finansowej) przekłada się na sytuację prawną szeregu innych podmiotów (klientów, inwestorów], to w interesie publicznym leży minimalizacja ryzyka jego działalności, w tym poprzez uregulowanie podstawowych zasad ładu korporacyjnego. Regulacja powinna być dostosowana do specyfiki danej branży. Rozwiązaniem z pewnością nie jest wprowadzanie zmian na poziomie przepisów powszechnych (Kodeksu spółek handlowych).

Naturalnym przykładem mogą być tutaj przepisy ustawy o działalności ubezpieczeniowej i reasekuracyjnej ${ }^{21}$ (dalej: u.dz.u.r). Rada nadzorcza ma możliwość bezpośredniego kontaktu (a w istocie rzeczy obowiazek) z osobami odpowiedzialnymi za compliance (art. 64 ust. 2 pkt 1 u.dz.u.r.) oraz audyt wewnętrzny (art. 65 ust. 4 w zw. z ust. 5 u.dz.u.r.). Ma to fundamentalne znaczenie dla efektywnego sprawowania nadzoru nad nadzorowanym podmiotem. Ponadto, zgodnie z Zasadami Ładu Korporacyjnego dla Jednostek Nadzorowanych ${ }^{22}$, powoływanie i odwoływanie osoby kierującej komórką audytu wewnętrznego oraz osoby kierującej komórką do spraw zapewnienia zgodności odbywa się za zgodą organu nadzorującego lub komitetu audytu ( $§ 49$ ust. 3 ZŁK).

19. A. Opalski, Komentarz do art. 384, nb. 1, [w:] Kodeks spółek handlowych. Tom III A. Spółka akcyjna. Komentarz do art. 301-392, [red.] A. Opalski, Warszawa 2016, Legalis 2021.

20. Por. D. Wajda, P. Tymczyszyn, Jeszcze o kolegialności działania rady nadzorczej w spółce akcyjnej, „Monitor Prawa Handlowego" 2020, nr 1, s. 8.

21. Ustawa o działalności ubezpieczeniowej i reasekuracyjnej (Dz.U. z 2021 r. poz. 1130, dalej: u.dz.u.r.).

22. Komisja Nadzoru Finansowego, Zasady Ładu Korporacyjnego dla Instytucji Nadzorowanych (ZŁK), Warszawa 2015. 
Przy analizowaniu przepisów nowelizacji nie sposób także nie odnieść się do przepisów art. 128-131 u.b.r., przewidujących obowiązek działania komitetu audytu w jednostkach zainteresowania publicznego, które swoim zakresem obejmuja m.in. zakłady ubezpieczeń i zakłady reasekuracji oraz główne oddziały i oddziały zakładów ubezpieczeń i zakładów reasekuracji²3. Projektodawcy zapominają wreszcie o potężnym sojuszniku rady nadzorczej, jakim są biegli rewidenci. Audytorzy (tzw. watchdogs) kontroluja czy sprawozdanie finansowe przedstawia rzetelny obraz sytuacji majątkowej i finansowej spółki, wspierając radę nadzorczą (w tym komitet audytu).

Jeżeli dołożyć do tego rozbudowane przepisy dotyczące zasad funkcjonowania zarządu i rady nadzorczej (w tym jej komitetów), w odniesieniu do instytucji finansowych, zasady dobrych praktyk spółek notowanych na GPW w Warszawie czy dobre praktyki Komisji Nadzoru Finansowego dla instytucji nadzorowanych, łatwo można wypełnić treścią ogólnie sformułowane prawa i obowiązki zarządu i rady nadzorczej wynikające z zasady współdziałania i lojalności. Czy naprawdę zarządy masowo ograniczają radom nadzorczym dostęp do informacji? Czy jeśli rada nadzorcza otrzyma dziesiątki tysięcy stron papieru (!) z informacjami, to spowoduje to bardziej, czy mniej efektywny nadzór? Czy naprawdę dotychczas rady nadzorcze nie mogły zatrudniać doradców? Czy naprawdę nie sporządzały sprawozdań ze swojej działalności? Czy naprawdę nie komunikowały się bezpośrednio z audytem wewnętrznym, compliance albo z innymi pracownikami w spółce?

Przepisy Kodeksu spółek handlowych były i są odpowiednie. Przepisy wymagaja po prostu odpowiedniego stosowania. Kodeks to nie instrukcja obsługi pralki automatycznej ani malaksera. Oczekiwanie, że w Kodeksie spółek handlowych zapiszemy instrukcję obsługi nadzoru nad spółką akcyjna, świadczy o całkowitym niezrozumieniu istoty problemu.

Warto w tym miejscu przytoczyć fragment uzasadnienia decyzji KNF z 20 sierpnia 2021 roku, nakładającej kary pieniężne na członków rady nadzorczej GetBack S.A. (wydanego oczywiście na gruncie przepisów sprzed projektowanej nowelizacji): „Odpowiedzialność, jaka ciąży na członkach rady nadzorczej Spółki, dotyczy zaniechań w zakresie nadzoru [...]. Członkowie rady nadzorczej nie wykazali należytej staranności i czujności, co mogło przyczynić się do niewykrycia nieprawidłowości w sprawozdawczości spółki. [ ... ] członkowie rady nadzorczej Spółki nie zapewnili stałego i odpowiedniego nadzoru nad wszystkimi obszarami działalności Spółki. Rada nadzorcza jest [...] organem spółki akcyjnej sprawującym stały nadzór nad wszystkimi dziedzinami jej działalności. Zakres kontroli sprawowanej przez radę nadzorczą obejmuje wszystkie czynności, które wpływają na sytuację spółki akcyjnej, a zatem niedopuszczalne jest, aby taki nadzór miał charakter wybiórczy. Na radzie nadzorczej spoczywa również obowiązek podejmowania działań niezbędnych do usunięcia nieprawidłowości wykrytych podczas bieżącej kontroli. Ma ona stale monitorować funkcjonowanie emitenta, w szczególności działalność jej organu zarządzającego. Rada nadzorcza powinna dostosować zakres i sposób sprawowanego nadzoru do charakteru działalności prowadzonej przez spółkę [...]. Powinna też uwzględnić wynikający z tej działalności poziom ryzyka. Im bardziej działalność spółki jest złożona lub istnieją w niej obszary generujące wysoki poziom ryzyka, tym wnikliwość nadzoru rady nadzorczej powinna być odpowiednio większa. Rada nadzorcza powinna wykazać się należytą starannością w wykonywaniu spoczywających na niej

23. Art. $128 \mathrm{w}$ związku z art. 2 punkt 9) lit. c) u.b.r. 
obowiązkach."24. To jest stanowisko KNF pod rządami obecnego Kodeksu spółek handlowych, który rzekomo promuje bierność rad nadzorczych.

Członek zarządu i rady nadzorczej odpowiadają wobec spółki za szkodę wyrządzoną działaniem lub zaniechaniem sprzecznym z prawem lub statutem spółki, chyba że nie ponoszą winy (art. 483 $\S 1$ k.s.h.). Przepis ten wprowadza domniemanie obowiązku działania członka rady nadzorczej. Aby uwolnić się od odpowiedzialności za zaniechanie, członek rady nadzorczej musi wykazać, że dołożył należytej staranności. Już obecne przepisy Kodeksu spółek handlowych wymagaja, aby członek rady nadzorczej był profesjonalistą (art. $483 \S 2$ k.s.h.), a więc potrafił sprawować skuteczny nadzór. To z kolei wymaga - wbrew temu, co pisza projektodawcy - aktywności pod rygorem osobistej odpowiedzialności prawnej ${ }^{25}$. Trzeba tylko - i aż - stosować istniejące przepisy. Jeżeli z jakichś przyczyn nie są one stosowane, to dodanie kolejnych przepisów (o poziomie legislacyjnym godnym instrukcji obsługi sprzętu AGD, a nie ustawy o randze kodeksu] nie zmieni takiego stanu rzeczy.

Biznes prywatny sobie z tym radzi, a jeżeli sobie nie radzi, to ponosi konsekwencje (patrz cytowany powyżej przykład GetBacku]. Z kolei w przypadku spółek z udziałem Skarbu Państwa autorzy zapominają, że ludzi wysokich kompetencji nie da się skodyfikować. Sprawny nadzór nad spółkami z udziałem Skarbu Państwa wymaga kompetentnych nadzorców, a nie przepisów równie infantylnych, co groźnych.

Warto w tym miejscu przytoczyć tezę, która postawił w wywiadzie dla „Newsweeka” (11-17 października 2021] Andrzej S. Nartowski, wieloletni prezes Polskiego Instytutu Dyrektorów. Istotę problemu nadzoru nad spółkami z udziałem Skarbu Państwa widzi on nie w braku odpowiednich mechanizmów prawnych, ale w „ornamentariuszach” powołanych w skład rad nadzorczych. Są to po prostu ludzie niekompetentni. Żaden przepis prawa tego nie zmieni. Corporate governance tworzą ludzie. Od ludzi należy zaczynać budowanie wysokich standardów. Czy Ministerstwo Aktywów Państwowych odpowiedzialne za projekt buduje wysokie standardy? Z pewnością „buduje” wiele przepisów. Szkoda, że groźnych dla biznesu prywatnego.

\section{Projektowane przepisy doprowadza paradoksalnie do pogorszenia pozycji akcjonariuszy}

Ograniczone ramy artykułu zestawione z objętością projektu nie pozwalają na odniesienie się do wszystkich zmian. Stąd konieczność skoncentrowania się na najważniejszych kwestiach.

Jednym z istotniejszych elementów reformy - a jednocześnie jednym z jej najsłabszych elementów - jest projektowany art. $380^{1}$ k.s.h. ${ }^{26}$ Zakłada on, że to zarząd będzie „pchał” informacje

24. Por. komunikat Komisji Nadzoru Finansowego z dnia 16 września 2021 r. w sprawie decyzji z dnia 20 sierpnia 2021 r. w sprawie nałożenia kar pieniężnych na byłych członków rady nadzorczej GetBack SA z siedzibą w Warszawie [obecnie Capitea SA z siedziba w Warszawie).

25. Por. zamiast wielu: A. Opalski, Komentarz do art. 483 k.s.h., nb. 31 [w:] Kodeks spółek handlowych. Tom IIIB. Spółka akcyjna. Komentarz. Art. 393-490, [red.] A. Opalski, Warszawa 2016, Legalis 2021. Zob. tam również dyskusję (w zasadzie głównie krytyczną względem orzecznictwa sądów powszechnych i Sądu Najwyższego) dotyczącą znaczenia miernika należytej staranności dla oceny bezprawności zachowań członków organów spółek prawa handlowego.

26. Ibidem. 
do rady nadzorczej i zwracał w ten sposób uwagę rady na istotne problemy w spółce. W zamyśle projektodawców ułatwi to sprawowanie nadzoru. Zarząd będzie przedstawiał radzie nadzorczej tylko istotne informacje, a rada szybko i sprawnie ustali - w oparciu o przedłożone dokumenty (papierowe) - rzeczywisty stan rzeczy.

Projektodawcy założyli, że członkowie rad nadzorczych spółek kapitałowych w Polsce nie są ani inteligentni, ani kompetentni. Stąd projekt zakłada, że zarząd jako nadzorowany powinien namawiać i edukować członków rad nadzorczych, aby nadzorowali... zarząd. Na tym nie koniec. To zarząd ma wskazywać członkom rad nadzorczych, jakie środki nadzoru nad zarządem są najbardziej adekwatne (sic!). Efekt praktyczny tego założenia dla skutków aktywizacji i edukacji rad nadzorczych dobrze ilustruje powiedzenie Winstona Churchilla: „Ale jutro będę trzeźwy, a pani madame, nadal będzie taka brzydka”. Wszak nieinteligentny i niekompetentny członek rady nadzorczej nie jest w stanie zachowywać się jak inteligentny i kompetentny właściciel. Rada nadzorcza ma działać w myśli powiedzenia „Pańskie oko konia tuczy”. Projektodawcy uważają, że powinno być odwrotnie, czyli „Koń ma tuczyć pańskie oko”.

Profesor Aleksander Doliński, zwany ojcem polskiego prawa spółek handlowych, pisał ponad 100 lat temu, w wydanej w 1908 roku monografii na temat wprowadzanej w monarchii habsburskiej spółki z 0.o. to tak: „Kto nie posiada [... ] takich wiadomości, jakie przy załatwianiu interesów tego rodzaju są potrzebne, nie powinien podejmywać się funkcyj członka rady nadzorczej, a jeśli je mimo to podejmuje, odpowiada za brak tych wiadomości [ ... ]. Wina jego leży w objęciu urzędu, do którego nie dorósł [...]"2?.

Systemowo funkcja rady nadzorczej powinna być postrzegana przez pryzmat cech aktywnego i inteligentnego właściciela. Wyłącznie wtedy można wymagać od niej efektywnego sprawowania nadzoru. Niewątpliwym novum tego projektu na skalę światowąjest to, że nadzorowany (zarząd) ma domagać się aktywności nadzorującego. Sposobem na aktywizację rady nadzorczej sa jednak odpowiednio ukształtowane i egzekwowane reguły odpowiedzialności za brak sprawowania należytego nadzoru.

Profesor Doliński pisał: „Najważniejszym [ ... ] obowiązkiem rady nadzorczej jest [ ... ] nadzór nad zarządcami (zawiadowcami [...]), [ ...] nad całą ich działalnością [ ...]; w tym celu obowiązana jest rada nadzorcza trwale informować się [...] o toku interesów spółki [..] z starannością porządnego przemysłowca. Zasięganie wiadomości o toku interesów spółki jest jedynie środkiem do celu, tj. do sprawowania nadzoru. Czy i jakich środków kontroli ma rada nadzorcza użyć, o tem rozstrzyga staranność porządnego przemysłowca [...]. [...] radzie nadzorczej przysługuja wszelkie środki prowadzące do celu. Że rada nadzorcza ma prawo do tak wszechstronnej kontroli administracyi, to nie ulega żadnej wạtpliwości"28.

Nie potrzeba jednak wielkiej wyobraźni, aby dostrzec, że efektem zmian będzie w najlepszym razie dramatyczny wzrost biurokracji, a tam, gdzie problem może faktycznie wystapić, dojdzie do rozmycia odpowiedzialności między zarządem i radą nadzorczą ze szkodą dla akcjonariuszy.

27. A. Doliński, Austryackie prawo spółek z ograniczonq odpowiedzialnościq, Oficyna Allerhanda, Warszawa 2021, s. 272.

28. Ibidem, s. 256-259. 
Założenie, że rada nadzorcza będzie dostawać tylko istotne, skondensowane informacje, jest po prostu infantylne ${ }^{29}$. W rzeczywistości zostanie ona bowiem zalana informacjami nieprzefiltrowanymi. W przypadku największych spółek z udziałem Skarbu Państwa mogą być to dziesiątki tysięcy dokumentów. U podłoża nie musi leżeć zła wola zarządu. Na wszelki wypadek zarząd będzie wolał przekazać więcej niż mniej informacji. Oczywistą konsekwencją tego stanu rzeczy będzie to, że członkowie rady nadzorczej, zamiast skupiać się na istotnych elementach działalności spółki, będą się przebijać przez strony (papierowe!) nieistotnych informacji. To tylko osłabi jakość nadzoru, a nie ja podniesie. Ten swoistego rodzaju „szum” informacyjny w sposób nieuchronny prowadzi do nieprzejrzystości sposobu zarządzania spółką oraz „zatonięcia” informacji istotnych w zalewie informacji nieistotnych.

Z perspektywy akcjonariuszy największym zagrożeniem jest to, że na członków rady nadzorczej przerzucone zostanie ryzyko, że w gąszczu informacji nieistotnych przekazano informację istotna, która im po prostu umknie. To z kolei prosta droga wywołania konfliktu interesów u członków rady nadzorczej. W razie ujawnienia się problemu powinni oni bowiem modelowo żądać od zarządu podjęcia odpowiednich działań zaradczych, a potencjalnie takich członków zarządu zawiesić albo nawet odwołać. Z drugiej jednak strony należy spodziewać się szantażu ze strony zarządu: przecież zarzạd informację o źródle problemu radzie nadzorczej przekazał (na stronie 22 145. z 56130 stron dokumentów przekazanych w roku X). Skoro nie było reakcji ze strony rady, to członkowie rady nadzorczej ponoszą winę w nadzorze. Członkowie rady będą w takiej sytuacji postawieni przed dylematem, czy w obawie przed odpowiedzialnością osobistą należy daną kwestię eskalować, czy ze szkodą dla akcjonariuszy problem jakoś ukryć.

Projektowana regulacja doprowadzi zatem do zatarcia funkcji organu zarządzającego i nadzorczego, a tym samym do rozmycia odpowiedzialności. Skoro winni są wszyscy, to winny nie będzie nikt, bo nikt nie jest zainteresowany, aby ustalić rzeczywisty stan rzeczy. Dokonanie odpowiedniej alokacji kompetencji pomiędzy organami spółki, zgodnie z funkcją danego organu, oraz określenie dopuszczalnych ram współdziałania organów spółki jest kluczowe z punktu widzenia skutecznego nadzoru właścicielskiego. Przywoływany już prof. Doliński w 1908 r. ujmował to tak: „W przedsiębiorstwach większych rozmiarów, więcej skomplikowanych nie może rada nadzorcza wykonywać tak

29. Jak trafnie wskazuje A. Opalski, od kontrolowanego trudno oczekiwać przedstawiania rzetelnych informacji, które moga go obciążać, stąd też autor - trafnie - poszukuje „uszczelnienia” tego mechanizmu poprzez możliwość weryfikacji informacji za przede wszystkim poprzez kontakt z audytem wewnętrznym i zewnętrznym (biegłym rewidentem): „Przypisanie podstawowego znaczenia sprawozdaniom zarządu rodzi nieuchronne ryzyko przekazywania nierzetelnych informacji (»ukrywania« przed rada niekorzystnych zjawisk). Od kontrolowanego nie sposób oczekiwać bezstronności, zwłaszcza tego, że zaprezentuje własne działania w niekorzystnym świetle. Jednocześnie prawo bezpośredniego zweryfikowania informacji przez radę jest słabym instrumentem dyscyplinowania zarządu. Rada nie zawsze ma wystarczające podstawy do stwierdzenia, że zachodzi konieczność sprawdzenia wiarygodności informacji, a zarząd może stosunkowo łatwo ukrywać nieprawidłowości. Ich wykrycie na podstawie dokumentów i rewizji stanu majątku może okazać się trudne. Pracownicy nie są zwykle skłonni do ujawniania krytycznych informacji o swoich przełożonych. Dlatego bardzo istotne znaczenie ma dostepp rady do niezależnych źródeł informacji, przede wszystkim do sprawozdań wewnętrznego audytu i opinii biegłego rewidenta oraz wyjaśnień tych osób. Dostęp ten ma następować za pośrednictwem komitetu audytu (por. pkt V). Sprawozdania zarządu i niezależne informacje o procesach zachodzących w spółce powinny wzajemnie się uzupełniać, tworząc kompleksowy system informowania rady" - A. Opalski, Komentarz do art. 382, nb. 22, [w: ] Kodeks spółek handlowych. Tom III A. Spółka akcyjna. Komentarz do art. 301-392, [red.] A. Opalski, Warszawa 2016, Legalis 2021. 
wszechstronnej kontroli [... ]. Trzebaby kontrolować nie tylko zarząd., ale wszystkich urzędników i pomocników spółki. [...] nawet członkowie dyrekcyi nie moga często objać całej administracyi i dlatego administracya musi być podzieloną na działy, które przydziela się poszczególnym członkom dyrekcyi. Taka wszechstronna kontrola, utrzymywanie ciagłego kontaktu z całym aparatem adoministracyjnym byłyby tedy wręcz niemożliwe do wykonania. [... ] rada nadzorcza nie może być zniewolona do ciągłego kontrolowania, lecz musi poprzestać na peryodycznych [...] rewizyach [...] musi poprzestać na próbach wyrywkowych"30.

Zobowiązanie członków rady nadzorczej do sprawowania nadzoru nad sposobem prowadzenia spraw spółki musi być możliwe do wykonania. Projekt w praktyce obliguje zarząd i zachęca go do uniemożliwienia radzie nadzorczej efektywnego sprawowania nadzoru. Znane są w praktyce przypadki, w szczególności w spółkach z udziałem Skarbu Państwa, gdy zarząd celowo angażuje radę nadzorczą w sprawy operacyjne, aby - jak była mowa wyżej - zdjąć z siebie odpowiedzialność za podejmowane decyzje zarzạdcze. Inną kwestiąjest, że nadmierna i zbyt szczegółowa kontrola nieuchronnie prowadzi do zaburzenia prac zarządu, który koncentruje się na gromadzeniu i przekazywaniu informacji radzie nadzorczej kosztem prowadzenia spraw spółki.

Podsumowując, nadmierne obowiązki informacyjne nieuchronnie prowadzą do przerzucania odpowiedzialności za zarządzanie spółką na radę nadzorcza, sprowadzając zarząd do roli organu wykonawczego. Jest to sprzeczne z zasadą współdziałania obu organów dla dobra spółki przy wykorzystaniu kompetencji zawodowych członków rady nadzorczej, sprowadza bowiem członków zarządu do roli posłusznych wykonawców uchwał rady nadzorczej. To osłabia materialne podstawy odpowiedzialności członków zarządu albo wręcz uchyla je. Z kolei wobec tego, że od rady nadzorczej nie można wymagać operacyjnego zaangażowania w sprawy spółki, osłabieniu, a nawet uchyleniu ulega odpowiedzialność rady nadzorczej.

Oceniany projekt formalizuje relacje między zarządem a radą nadzorczą w każdej spółce kapitałowej, promując głęboki brak zaufania w stosunkach wewnętrznych spółki. Formalizm prowadzi do zwiększenia kosztów działania spółki kapitałowej bez względu na jej wielkość. Komunikacja wewnątrz spółki ma być sformalizowana. Na wszystko musi być „kwit”. Projekt prowadzi do ukształtowania organów spółki jak w „urzędzie”.

\section{Przepisy karne jako oręż politycznej zemsty}

Niejako na uboczu zmian dotyczących rad nadzorczych proponuje się nowelizację przepisów karnych Kodeksu spółek handlowych. W nierównej walce między zarządem a radą nadzorczą o dostęp do informacji tę druga wyposaża się bowiem w Wunderwaffe w postaci odpowiedzialności karnej członków zarządu z tytułu nieprzekazania żądanych przez radę nadzorczą informacji w terminie, tj. w sposób sprzeczny z projektowanym art. $382 \S 4$ oraz $4^{1}$ k.s.h. (projektowany art. $587^{1}$ k.s.h. ${ }^{31}$ ).

Projektodawcy idą o krok - a nawet o kilka kroków - dalej. Otóż odpowiedzialności karnej podlegać mają nie tylko członkowie zarządu, ale także: „prokuren[ci], likwidato[rzy], os[oby] zatrudnion[e] w spółce na podstawie umowy o pracę lub wykonując [e] na rzecz spółki w sposób

30. Ibidem, s. 259.

31. Cytowane powyżej. 
regularny określone czynności na podstawie umowy o dzieło, umowy zlecenia albo innej umowy o podobnym charakterze"32. To już całkiem pokaźna grupa.

Co więcej, odpowiedzialności karnej podlegają nie tylko osoby, które nie przekazały posiadanych informacji, ale także te, które stosownych „informacji, dokumentów, sprawozdań lub wyjaśnień dotyczących spółki, w szczególności jej działalności lub stanu majątkowego" nie sporządzi$\nmid y^{33}$. Jak daleko idzie obowiązek dołożenia należytej staranności w tworzeniu sprawozdań - o tym rozstrzygna prokuratorzy i sądy karne.

Na tym jednak projekt nie poprzestaje. Otóż odpowiedzialności karnej podlegać będzie nie tylko nieprzekazanie informacji, ale także nieterminowe jej przekazanie. Członkowie zarządu, ale także prokurenci, pracownicy oraz współpracownicy spółki, będą musieli pracować szybko. W projektowanym art. $382 \S 4^{1}$ k.s.h. proponuje się bowiem, aby nie tylko informacje, ale także tworzone specjalnie sprawozdania lub wyjaśnienia, były przekazywane radzie nadzorczej: „niezwłocznie, nie później niż w terminie dwóch tygodni od dnia zgłoszenia żądania do organu lub osoby obowiązanej, chyba że w żądaniu określono dłuższy termin”. Warto zwrócić uwagę, że nawet przekazanie informacji w terminie dwóch tygodni nie gwarantuje członkom zarządu, pracownikom, ani współpracownikom spokojnego snu. Być może można było bowiem odpowiedzieć szybciej (bez zbędnej zwłoki]. Znów, czy taka możliwość była - zdecyduja prokuratorzy i sędziowie.

Aby uniknać ryzyk związanych z koniecznością udowadniania przez oskarżycieli umyślności (byłym) członkom zarządu, pracownikom czy współpracownikom spółek, projektodawcy proponuja, aby przestępstwo z art. $587^{1}$ k.s.h. można było popełnić także nieumyślnie ( $§ 2$ powołanego przepisu). Wspaniałomyślnie sankcja nie jest nawet przerażająca - w przypadku czynu popełnionego nieumyślnie grzywna nie niższa niż 6000 złotych i nie wyższa niż 20000 złotych.

Na tym jednak konsekwencje się nie kończą. Otóż, zgodnie z brzmieniem nowelizowanego art. 18 § 2 k.s.h., zakaz pełnienia funkcji w spółkach kapitałowych ( w tym przede wszystkim funkcji członka zarządu, rady nadzorczej, lub prokurenta) dotyczyć ma osób skazanych prawomocnym wyrokiem za przestępstwo określone w art. $587^{1}$ k.s.h. Osoba skazana nie będzie mogła pełnić funkcji przez okres 5 lat od dnia uprawomocnienia się wyroku skazującego (art. $18 \S 2$ k.s.h.).

Trudno zrozumieć, co kierowało projektodawcami. Tak określony przepis karny w oczywisty sposób nie spełnia standardów konstytucyjności w zakresie wymagań co do pewności norm o charakterze karnym. Czym są bowiem: „wszelki[e] informacj[e], dokument[y], sprawozda[nia] lub wyjaśnie[nia] dotyczac[e] spółki, w szczególności jej działalności lub stanu majątkowego"? Jaki termin na ich przekazanie jest pozbawiony zbędnej zwłoki? Czy pracownik spółki, który lekkomyślnie lub niedbale nie odpowie radzie nadzorczej w terminie 14 dni na pytanie (albo odpowie na pytanie niekompletnie), może już tylko czekać, aż prokuratura go oskarży, a sąd skaże na przestępstwo z art. $587^{1} \S 2$ k.s.h.? Czy z tego powodu osoba taka nie daje już rękojmi do pełnienia jakiejkolwiek funkcji w spółce kapitałowej przez 5 lat?

Projektowany art. $587^{1}$ w zw. z art. 382 § 4 i $4^{1}$ k.s.h. to w praktyce szczególne zagrożenie dla spółek z udziałem Skarbu Państwa. Jest bowiem tajemnica poliszynela, że rotacje kadrowe są w tych spółkach najczęstsze i najdalej idące. Dzięki nowelizacji rady nadzorcze zyskają potężny instrument z zakresu polityki kadrowej. Niepotrzebne będą bowiem odwołania z funkcji członków zarządu czy wypowiedzenia dla pracowników. Po pierwszym zażądaniu przez radę nadzorczą

32. Projektowany art. $587^{1}$ w zw. z art. $382 \S 4$ k.s.h. (cytowane powyżej).

33. Projektowany art. $382 \S 4$ k.s.h. (cytowane powyżej). 
odpowiednio obszernego sprawozdania osoby takie same zrezygnuja w obawie przed odpowiedzialnością karną i zakazem pełnienia funkcji w spółkach kapitałowych przez 5 lat od daty skazania.

\section{Podsumowanie}

Projektowana nowelizacja ma w ocenie projektodawców aktywizować rady nadzorcze do działania, poprzez wyposażenie ich w „nowe” obowiązki. Natomiast, jak już zostało wskazane w niniejszym artykule, na tle przepisów projektowanej nowelizacji może dojść co najwyżej do:

1) rozmycia odpowiedzialności zarządu i rady nadzorczej, a w praktyce - próby wyłączenia tej odpowiedzialności. Rady nadzorcze największych spółek z udziałem Skarbu Państwa zostana zalane dziesiątkami tysięcy stron papieru, a jeżeli członkowie rad nadzorczych nie dostrzega wśród takich informacji tych potencjalnie problematycznych, będa ponosić odpowiedzialność za nierzetelny nadzór. Jeżeli w przyszłości problem się ujawni, to członkowie rad nadzorczych zostana postawieni przed dylematem, czy w obawie przed odpowiedzialnością osobistą dana kwestię eskalować, czy wspólnie z zarządem ukryć problem przed akcjonariuszami. Skoro odpowiedzialni są wszyscy, tj. i zarząd, i rada nadzorcza ${ }^{34}$, to rada nadzorcza nie będzie zainteresowana ustalaniem prawdziwego stanu rzeczy. Łatwo domyśleć się, że taki układ jest w szczególności korzystny dla polityków kontrolujących de facto spółki z udziałem Skarbu Państwa, ale mechanizm ten może być, i zapewne będzie, wykorzystywany w spółkach prywatnych (zob. kazus GetBack). Polska będzie powtarzać dzięki temu projektowi najbardziej reprezentatywne afery corporate governance, które miały miejsce w Europie i USA;

2] pozbawienia wielu osób, które popadły w „niełaskę” władzy, prawa do pełnienia funkcji w spółkach przez okres kolejnych 5 lat. Projektowane przepisy dotyczące obowiązków informacyjnych ${ }^{35}$ w zestawieniu z przepisami karnymi ${ }^{36}$ oraz nowelizowanym art. $18 \S 2$ k.s.h. ${ }^{37}$ powoduja, że nawet za nieumyślne nieprzekazanie albo brak niezwłocznego przekazania radzie nadzorczej informacji uznanych przez prokuratora i sąd za istotne (co wobec częstego braku kompetencji sądów i prokuratury do merytorycznej oceny biznesowej istotności informacji może skutkować patologiami] nie tylko członkowie zarządu, ale także pracownicy i współpracownicy (czyli każdy kto świadczy usługi na rzecz spółki), mogą w łatwy sposób zostać pozbawieni prawa do pełnienia funkcji w spółkach handlowych przez 5 lat (sankcja z art. 18 k.s.h.).

$\mathrm{Na}$ tle powyższego należy dojść do wniosku, że wady projektu mają tak fundamentalny charakter, że dyskwalifikuja go w całości. Projekt nie tylko został oparty na błędnych założeniach, ale został także w karykaturalnie wręcz zły sposób napisany. Ponadto stanowi on symboliczny koniec Kodeksu spółek handlowych jako kodeksu, czyli podstawowej ustawy prawa prywatnego. Przyjęte podejście prowadzi do dalszej destabilizacji i dezintegracji prawa spółek handlowych w sferze wartości, podstawowych konstrukcji i pojęć.

34. Por. S. Sołtysiński, P. Moskwa, nb. 28, [w:] System Prawa Prywatnego. Tom 17B, [red.] S. Sołtysiński, Warszawa 2016, Legalis 2021.

35. Projektowany art. $382 \S 4$ k.s.h., art. $382 \S 4^{1}$ oraz art. $382^{1} \S 4$ k.s.h.

36. Projektowane art. $587^{1}$ k.s.h. oraz art. $587^{2}$ k.s.h.

37. Projektowany $18 \S 2$ k.s.h. 
Co istotne, projektodawcy zapominają o tym, że zarządy i rady nadzorcze tworzą ludzie. To od ludzi należy zaczynać budowanie wysokich standardów. Przepisami prawa nie zapewni się kompetencji nadzorczych. Można co najwyższej skodyfikować własną niekompetencję.

\section{Wykaz źródeł}

Doliński A., Austryackie prawo spółek z ograniczonq odpowiedzialnościq, Oficyna Allerhanda, Warszawa 2021.

Komunikat Komisji Nadzoru Finansowego z dnia 16 września 2021 r. w sprawie decyzji z dnia 20 sierpnia 2021 r. w sprawie nałożenia kar pieniężnych na byłych członków rady nadzorczej GetBack SA z siedzibą w Warszawie (obecnie Capitea SA z siedzibą w Warszawie).GUS, Zmiany strukturalne grup podmiotów gospodarki narodowej w rejestrze REGON, 2020 r., Warszawa 2021. KNF, Zasady Ładu Korporacyjnego dla Instytucji Nadzorowanych, Warszawa 2015.

Opalski A, [w: ] Kodeks spółek handlowych. T. III A. Spółka akcyjna. Komentarz do art. 301-392, Opalski A. [red.],Warszawa 2016, Legalis 2021.

Opinia Rady Legislacyjnej przy Prezesie Rady Ministrów z 16 października 2020 r. o projekcie ustawy o zmianie ustawy - Kodeks spółek handlowych oraz niektórych innych ustaw ( $\mathrm{Nr}$ RL-033-28/20).

Wajda D., Tymczyszyn P., Jeszcze o kolegialności działania rady nadzorczej w spółce akcyjnej, „Monitor Prawa Handlowego”, Warszawa 2020.

Sołtysiński S., Moskwa P. [w:] Prawo spółek kapitałowych. System Prawa Prywatnego. Tom 17B, Sołtysiński S. [red.], Warszawa 2016, Legalis 2021.

Szwaja J., Mika I., [w:] Kodeks spółek handlowych. Komentarz. Tom 3, Sołtysiński S., Szajkowski A., Szumański A. [red.], Warszawa 2013, Legalis 2021.

Popiołek W., [w:] Kodeks spółek handlowych. Komentarz, Strzępka J. [red.], Warszawa 2015, Legalis 2021.

\section{Assessment of the provisions on the functioning of Supervisory Boards in relation to the draft of the bill amending the Code of Commercial Companies and certain other acts}

The purpose of this article is to assess the provisions on the functioning of supervisory boards, also in the context of joint stock companies conducting insurance activity, in relation to the draft of the bill amending the Code of Commercial Companies and certain other acts (Journal of Laws No. 1515)

The bill is presented as a mechanism to activate supervisory boards and is based on the assumption that current regulations are designed to promote passivity among board members. The supervisory board is supposed to be passive because it would not have the tools for effective supervision. The extensive regulations on corporate governance in financial institutions (including insurance companies in particular] were completely ignored.

The draft is based on erroneous assumptions and proposes solutions that may paralyze the functioning of supervision in joint-stock companies in an ill-developed (and sometimes even infantile) 
manner. Contrary to the declared intentions of the drafters, it may in fact result in weakening the protection of shareholders' interests.

Keywords: supervisory board, audit committee, joint stock companies, disclosure obligations.

PROF. DR HAB. MICHAŁ ROMANOWSKI - profesor prawa w Katedrze Prawa Handlowego na WPiA Uniwersytetu Warszawskiego; adwokat i partner w kancelarii Romanowski i Wspólnicy

Orcid: 0000-0003-1065-0958

e-mail:m.romanowski@romanowski.eu

PIOTR HAIDUK - adwokat i partner w kancelarii Romanowski i Wspólnicy

e-mail: p.haiduk@romanowski.eu 